\title{
A MÁTRA TURISZTIKAI TELJESÍTMÉNYE ÉS LEGÚJABB TURISZTIKAI TRENDJEI
}

\author{
Benkő Béla - Szőke Szilvia - Gyurkó Ádám \\ Zsarnóczky Martin - Bujdosó Zoltán
}

\section{Összefoglalás}

A Mátra az Észak-magyarországi régióban, Heves megyében és Nógrád megyében található, mely bár két megyét érint mégis földrajzi egységként jól körülhatárolható, és márkásitható turisztikai termék. A tanulmány célja, hogy statisztikai adatokkal és terepi felmérésekkel igazolt új trendeket mutasson be, illetve értékelje a desztináció turisztikai teljesitményét a hazai piacon.

Kulcsszavak: Turisztikai teljesitmény, turisztikai trend, Mátra

JEL: J51

\section{TOURISTIC PERFORMANCE AND NEW TRENDS IN MÁTRA TOURISTIC DESTINATION}

\begin{abstract}
Mátra is located in the Northern - Hungary. region including Heves and Nógrád counties. Although the mountain covers two counties, Mátra is a unique region which easily can be limited and understood as a common brand. The aim of the study is to show the new touristic trends supported by statistic data and field reserach. The other goal is to evaluate the touristic performance of the destination in the Hungarian market.
\end{abstract}

Keywords: Touristic performance, touristic trends, Mátra destination JEL:J51 


\section{Helyzetelemzés}

A Mátra az Észak-magyarországi régióban, Heves megyében és Nógrád megyében található, mely bár két megyét érint mégis földrajzi egységként jól körülhatárolható, és márkásítható turisztikai termék.

A keresleti és kínálat alakulásának vizsgálatához elengedhetetlen a Mátravidék turisztikai környezetének általános jellemzésének elvégzése.

\section{Vonzerök}

Mátra turizmusa jelenleg nem egy kiemelkedő attrakcióra épül, hanem a turisták helyszínre vonzásával kapcsolatos több, érdekes elemre. Jelenleg a terület magas vonzásértékü adottságokkal rendelkezik, közepes turisztikai infrastruktúrával, mely kiindulási helyzet koncepcionált marketingmunkával jól erősíthető és térségi szinten is integrálható eredményt hozhat. Fontos azonban kiemelni, hogy a meglévő vonzerők környékén történő infrastruktúra fejlesztés nagyban elősegítené a marketing kommunikációt egyszerűen az élményszerű időtöltéssel.

A Mátravidék az idegenforgalmi szempontból vonzó látnivalók gazdag tárházát kínálja. A természeti adottságok közül kiemelkedik a hegység Magyarország legmagasabb pontjával (Kékestető 1014 m), valamint a hegyvidék legjelentősebb üdülő és gyógyhelyei. Történelmi nevezetességek és müemlékek csoportját képezik a várak és kastélyok, a múzeumok, tájházak és kiállítóhelyek, valamint a siroki barlanglakások. A Mátraaljai Történelmi Borvidék az ország 22 borvidéke közül országosan a második, a hegyvidékek között pedig a legnagyobb. A térség termál- és ásványvizei gyógyászati célokra történő hasznosításának legjobb példái a parádi víz és a bükkszéki fürdő. A Mátra erdősége a vadászok kedvelt célterülete. A természeti és ökoturizmust kedvelők télen-nyáron kedvező feltételeket találnak a Mátrai Tájvédelmi Körzet területén, a sportolni vágyók pedig a hegység sípályáin, erdeiben. A Mátra hegység magasabb színvonalú hoteljei az üzleti és rendezvényturizmus helyszíneiként jelentkeznek. A Mátravidéken minden adottság megvan mind a közúti, mind pedig a hegyvidéki kerékpározáshoz. A vidéki (falusi és agro-) turizmus jó adottságokkal rendelkezik a térségben, ugyanis számos szép település, sajátos népi szokás és életmód, mesterség, építészet, és népi kultúra található meg. A néprajzi hagyományok a térség unikális értékei, így az ősmagyar, a palóc és a szlovák néprajzi emlékek és kézműves hagyományok.

Összegezve elmondhatjuk, hogy a természeti turizmus már létező, népszerü termékként jelenik meg, amíg az aktív turizmus, a kulturális turizmus és a borturizmus jelentős, de fejlesztendő, potenciális termékei a desztinációnak, továbbá a rendezvényturizmus és egészségturizmus egyelőre másodlagos termékként azonosítható (Bujdosó - Remenyik, 2008, Benkő et al., 2018). 
Fentebb került említésre az is, hogy az adottságok rendelkezésre állnak, de mégis a korábbi évek tapasztalatai azt mutatják, hogy az ötlet, tervezés és a megvalósítás között az adminisztrációs kötöttségek miatt, még a magánjellegü beruházások is lassan haladnak.

A kínálatot vizsgálva elmondhatjuk, hogy a térség közúti hálózata fejlett, az M3as autópálya biztosítja a gyorselérhetőséget. A Mátra-vidéken a településeket kivétel nélkül szilárd burkolatú utak kötik össze. A térség déli részét érintő Budapest-Miskolc, Hatvan-Salgótarján vasútvonal, valamint a Vámosgyörk-Gyöngyös vonalak villamosítottak.

A Mátra-vidék valamennyi településén biztosított az infrastrukturális alapellátás. A közművek alapvetően kiépítettek, a Felső-Mátra vidékén szükséges a jelenlegi csatornahálózatot fejleszteni, illetve az elektromos áramellátást a nagyobb biztonságú hozzáférést nyújtó földkábeles kivitelüre szükséges cserélni. A vízhálózat ellátás megoldott, fontos a modern telefonos és szélessávú internetes szolgáltatás eljuttatása minden településre.

A Mátra szállásférőhelyei összetételéről megállapítható, hogy a vidéki átlagnál sok tekintetben kedvezőbb a szerkezete, hiszen a szálloda típusú és bizonyos konkrét szállodatípus vonatkozásában a megoszlás magasabb annál. Az országos átlaghoz képest a $4^{*}$-os szállodák férőhelyei némileg alacsonyabbak a Mátrában, míg a legmagasabb, $5^{*}$-os férőhelyek aránya az országos átlag körüli, a régióban a legjobb (itt található Magyarország első vidéki $5^{*}$-os kastélyszállója a Kastélyhotel Sasvár). A panziók férőhelyeinek aránya magasabb, mint a vidéki átlag. Viszonylag magas a térségben a turistaszállók, üdülőházak és az ifjúsági szállók szállásférőhelyeinek aránya, míg a kempingeké a vidéki átlagnál picit alacsonyabb. A térség településein a magán szállásadás valamivel elterjedtebb.

A Mátra vidéken több mint száz étterem biztosítja a turisták, illetve a helyi lakosság számára a vendéglátást. Ezek közül ki kell emelni a térség nemzetiségeihez, néprajzi csoportjaihoz (szlovákok, palócok) és hagyományaihoz kapcsolódó vendéglátóhelyeket, hiszen ezek jelentik a térség egyedi kulináris értékeit.

A térség legfontosabb általános és turisztikai szolgáltatásait elsősorban a nagyobb településeken működő vállalkozások, valamint az utazási irodák és utazásszervezők biztosítják. Szabadidős programszervezésben a települési önkormányzatok, szervezeti egységei, esetenként civil szervezetek, illetve az egyes szálláshelyek szolgáltatói vesznek részt.

A Mátravidék kereskedelmi ellátottsága régiós és országos viszonylatban is jónak mondható, a kereskedelmi egységek teljes vertikuma (kisbolttól a hipermarketig) jelen van a térségben, a települések kategóriájára jellemző súlynak megfelelően.

A térség valamennyi településén több rendőrkapitányság alatt rendőrőrsök müködnek, valamint kialakult a polgárőri hálózat is. A bűncselekmények számát tekintve a térség az országos átlagtól jóval elmarad. Ezek természetesen hozzájárulnak ahhoz a tényhez, hogy a Mátra összességében „biztonságos desztinációként fogható fel”. 
Az egészségügyi ellátás a térségben kitűnőnek mondható, hiszen az országos átlagot meghaladó kórházszám mellett valamennyi településen biztosított a nagyságának megfelelő ellátás, és a térségben az egészségügyi ellátás teljes skálája (orvosi rendelőtől az országos jelentőségű szakkórházig) megtalálható.

Nemzetközi jelentőségű fesztiválok, programok illetve nagyobb számú turistát vonzó események a térségben megtalálhatók. A gyöngyösi Tourinform irodához kapcsolódóan idegenvezetői szolgáltatás biztosított, ezt erősíti az Eszterházy Károly Egyetem, Károly Róbert Campusa által esetenként szervezett idegenvezetést biztosító képzése.

A rendezvény- és programszervezés elsősorban az önkormányzatok, illetve a társulások illetékes szakembereihez kapcsolódik. A vállalkozói aktivitás az országos átlag fele, térségben jellemzően kis és középvállalkozások működnek. (Baranyi et al. 2015)

\section{Kereslet}

Az idegenforgalom területén folytatott munka sikerességét a legtöbb esetben a célterületen kívülről érkező turisták számának az emelkedésével szokták lemérni. Ennek hátterében két tényező áll (Dávid et al., 2008, Bujdosó , 2009).

Egyrészt ezen turisták révén lehetővé válik a térségen kívül megtermelt jövedelmek ide csábítása, és ennek eredményeként a helyi GDP emelkedése (Bujdosó et al., 2011). Másrészt a külső turisták számának az emelkedése az, amely igazán bizonyítja az idegenforgalom területén megtett lépések eredményességét, és így növeli a lakosság (de különösen a turizmusban foglalkoztatottaknak) az önbizalmát, elégedettségét.

\section{A Mátra Vendégforgalma}

Magyarországon a Központi Statisztikai Hivatal adatai szerint 2016-ban a kereskedelmi szálláshelyet igénybe vevő vendégek száma 11117294 fö, 2017-ben 11883 929 fó, míg 2018 évben 12548170 fó, mely országos viszonylatban 105,6\% növekedés mutat. Vendégéjszakákat tekintve 2016-ban 27629453 éj, 2017-ben $29768770 \mathrm{ami}$ $107,7 \%$ növekedést jelent! 2018-ban 104,2\%-kal növekedett a vendégéjszaka szám, 31011261 éj.

A Mátra tekintetében a vendégéjszakák száma és a vendégek száma a következőképpen alakult kereskedelmi szálláshelyeken. 


\begin{tabular}{|c|c|c|c|c|c|c|c|c|}
\hline & $\begin{array}{c}\text { Vendégek száma } \\
\text { a kereskedelmi } \\
\text { szálláshelyeken } \\
\text { (fö) }\end{array}$ & & \multicolumn{2}{|c|}{$\begin{array}{c}\text { Változás } \\
\%\end{array}$} & $\begin{array}{c}\text { Vendégéjszakák } \\
\text { száma a kereske- } \\
\text { delmi szálláshe- } \\
\text { lyeken (db) }\end{array}$ & $\begin{array}{c}\text { Változás } \\
\%\end{array}$ \\
\hline & 2016 & 2017 & 2018 & & 2016 & 2017 & 2018 & \\
\hline & & & & & & & & \\
\hline Gyöngyös & 82907 & 98490 & 97659 & $99 \%$ & 165476 & 206625 & 197106 & $95 \%$ \\
\hline Mátraszentimre & 50982 & 53144 & 51492 & $97 \%$ & 123484 & 131309 & 126699 & $96 \%$ \\
\hline Parád & 26816 & 26999 & 26840 & $99 \%$ & 69280 & 68285 & 69999 & $103 \%$ \\
\hline Parádsasvár & 11408 & 14016 & 14984 & $107 \%$ & 24908 & 30610 & 33246 & $109 \%$ \\
\hline Sirok & 637 & 562 & n.a. & & 1514 & 1488 & n.a. & \\
\hline & & & & & & & & \\
\hline Összesen & 172750 & 193211 & 190975 & $99 \%$ & 384662 & 438317 & 427050 & $97 \%$ \\
\hline
\end{tabular}

\section{1. táblázat: A Mátra vendégforgalma}

Forrás: KSH, saját szerkesztés

A Mátra térségében a legdinamikusabb fejlődés Parádsasváron volt tapasztalható, ahol is a vendégek száma 107 \%-kal növekedett. Ugyanez mondható el a vendégéjszakák számáról, legnagyobb mértékben Parádsasváron emelkedett, 109\%-kal.

Gyöngyös, Mátraszentimre és Parád tekintetében minimális visszaesés tapasztalható a vendégek számában. Vendégéjszakákat illetően azonban Parádon 103 \%-os az emelkedés.

Sirokban 2018-ban nincs elérhető adat.

A külföldi vendégforgalom a 2. táblázat adatai szerint alakult

\begin{tabular}{|c|c|c|c|c|c|c|c|c|}
\hline & \multicolumn{2}{|c|}{$\begin{array}{c}\text { Külföldi vendégek } \\
\text { száma a kereske- } \\
\text { delmi szálláshelye- } \\
\text { ken (fó) }\end{array}$} & \multirow[b]{2}{*}{2018} & \multirow[t]{2}{*}{$\begin{array}{c}\text { Változás } \\
\%\end{array}$} & \multicolumn{2}{|c|}{$\begin{array}{l}\text { Külföldi vendé- } \\
\text { géjszakák száma a } \\
\text { kereskedelmi szál- } \\
\text { láshelyeken }(\mathrm{db})\end{array}$} & & $\begin{array}{c}\text { Változás } \\
\%\end{array}$ \\
\hline & 2016 & 2017 & & & 2016 & 2017 & 2018 & \\
\hline Gyöngyös & 5666 & 6821 & 5599 & $82 \%$ & 18538 & 23847 & 20803 & $87 \%$ \\
\hline Mátraszentimre & 762 & 598 & 634 & $106 \%$ & 2034 & 1597 & 1607 & $101 \%$ \\
\hline Parád & 386 & 770 & 749 & $97 \%$ & 967 & 2249 & 1942 & $86 \%$ \\
\hline Parádsasvár & 284 & 341 & 263 & $77 \%$ & 647 & 865 & 637 & $74 \%$ \\
\hline Sirok & 17 & 11 & n.a. & & 34 & 11 & n.a & \\
\hline Összesen & 7115 & 8541 & 7245 & $85 \%$ & 24236 & 28569 & 24989 & $87 \%$ \\
\hline
\end{tabular}

2. táblázat: A Mátra külföldi vendégforgalma

Forrás: KSH, saját szerkesztés 
A minőségi szálláshelykínálat lehetővé teszi, hogy ne csak egynapos kirándulásokat tegyenek a külföldiek hanem, több napra is megszálljanak a térségben. Mátraszentimre tekintetében 106 \%-os változás tapasztalható, míg Parád, Parádsasvár és Gyöngyös tekintetében egy kis visszaesés tapasztalható a külföldiek számát illetően. Külföldi turistákra jellemző, hogy hosszabb időt töltenek az országban illetve az adott területen, így az átlagos tartózkodási idő az ő esetükben magasabb, mint a belföldi turistáknál, mely 2,5-3,4 napra tehető.

A főbb küldő országok továbbra is Németország, Hollandia, Lengyelország Csehország és Szlovákia.

\section{Marketing tevékenység}

Az elmúlt években az online kommunikáció felé tolódik a hangsúly, mégis a térség kommunikációjában és népszerüsítésében megjelenik a print média, pr kampányok és a televízió megjelenés is. Természetesen nem maradhat el a vásári, kiállítási megjelenés sem, mely fóként az alföldi területekre - Szolnok, Debrecen és Budapestre koncentrálódik, hiszen a felmérések alapján e terültek a térség főbb küldő területei.

Fontos kiemeltünk, hogy számos marketing kutatás bizonyítja, hogy maga az online platformok felhasználásában is változás tapasztalható. Az asztali gépekről történő internet felhasználás mind háttérbe szorul a tabletek és az okos telefonok javára. A turisztikai verseny kiélezett, így tehát fontos a különböző online felületek responsivá tétele. A Gyöngyös-Mátra Turisztikai Közhasznú Egyesület 2018. évben a honlapját teljesen ennek rendelte alá, mely mellett további facebook és instagram kampányokkal is számol. Jelenleg a legnaprakészebb honlap, mely a térség látnivalóit mutatja be.

\section{Programok}

Mátra térségében számtalan program várja az érdeklődőket. Májustól kezdődően szinte nincs olyan hétvége, hogy ne lenne valamiféle turisztikailag frekventált program. Teljesség igénye nélkül a Mátrai Bornapok, Szüreti Fesztivál, Mátrai Múzeumok Éjszakája, Kisnánai és Siroki Várnapok, Gyöngy Néptáncfesztivál, Párnafesztivál, különböző teljesítménytúrák stb.

Programokról részletesen a turisztikai honlapokon, facebookon és hírlevélben tájékozódnak az érdeklődök, de Mátrai programfüzet is készül.

Programok tekintetében azt is láthatjuk, hogy vannak olyan időszakok, amikor jelentős mennyiségü program koncentrálódik egy-egy hétvégére. 


\section{Kiadványok}

Turisták számára releváns kiadványokból egy párat említenék meg, 10 nap sorozat, mely túrajánlatokat, természeti értékeket mutat be, a Mátrát bemutató átfogó turisztikai látnivalós térkép, és a programfüzet, melyek még bizonyos korosztály számára vonzóbb és könnyebben kezelhető, mint az online felületek.

Mátrát bemutató anyag a kedvcsináló kiadvány mely szálláskatalógussal ötvözve mutatja be a térséget.

\section{Együttmüködések}

A „Mátra Térségi TDM” Nonprofit Kft a Mátra népszerüsítése és fejlesztése érdekében fóként a tulajdonosain keresztül (Gyöngyös-Mátra Turisztikai Közhasznú Egyesület és a Mátra Jövője Egyesület) a következő szervezetekkel működik együtt:

- Megyei Közgyülés

- Magyar Turisztikai ügynökség

- Heves Megyei Kereskedelmi és Iparkamara

- Eger Térsége TDM

- Egererdő Zrt.

- Mátra térségi Önkormányzatok

- Civil szervezetek

- Magyar Természetjáró Szövetség

- Mátrai Önkormányzatok Szövetsége

- Dél-Mátra Közhasznú Egyesület

- Bükki Nemzeti Park

\section{Összegzés}

Mátra kiváló turisztikai adottságának köszönhetően sajnos a korábbi évhez képes csekély visszaesést mutatott. Ennek a hátterében részben a Gyöngyös-Mátra Közhasznú Egyesületnél rendelkezésre álló kevesebb marketing forrás részben pedig a térség vonzerőinek megújulása állhat, mely szorosan összeforr a kiszolgáló létesítmények és az infrastruktúra bizonyos hiányával is. A fejlődés fenntartásához fontos a stratégiai konstruktív együttgondolkozás. Cél az aktív és egészségturisztikai kínálat és a borturizmus fejlesztése, de a turisztikai kínálaton kívül fontos stratégia lépés az fejlődéshez elengedhetetlen infrastruktúra fejlesztés, illetve az engedélyeztetési jogszabályok egyszerüsítése. 
Jelenleg mind a Mátra, mind a Bükk térség fejlesztése érdekében fontos lenne, a kiemelt turisztikai területé történő nyilvánítás, mely lehetőséget a koncentrált szakmai fejlesztésre. A szakmai munkában fontos szerep hárul mind a térségi, mind pedig a helyi TDM szervezetekre.

Átfogó kampányok és termékfejlesztés, illetve a meglévő vagy új attrakciók népszerüsítése érdekében érdemes lenne egy szakmai alapokon nyugvó átfogóbb megyei támogatási rendszer kidolgozása.

\section{Hivatkozott források}

[1.] Baranyi A.-Taralik K. (2015): The Role of sub-regions "Heves" and "Bátorterenye" in the economic development, Journal of Central European Green Innovation 3 pp. 107-118. Paper: HU ISSN 2064-3004

[2.] Benkő B. - Domán Sz. - Szűcs- Cs. (2018): A Mátra, mint márka, 2018., I. Nemzetközi Turizmusmarketing Konferencia, Pécs, pp.63-70

[3.] Bujdosó Z.- Remenyik B. (2008) A hazai turisták életminőségének a feltérképezése az Észak-Magyarország Régióban In: Dávid L (szerk.) A turizmus szerepe az Észak-Magyarország Régióban I-II Gyöngyös: Károly Róbert Főiskola, pp 40-48 (2008)

[4.] Bujdosó, Z. (2009). A megyehatár hatása a városok vonzáskörzetére Hajdú-Bihar megye példáján Debrecen, Magyarország : Debreceni Egyetemi Kiadó, 211 p.

[5.] Bujdosó, Z.; Dávid, L. ; Remenyik, B. and Tóth, G. (2011). Connection between tourism and regional development on the Hungarian-Croatian border Central European Regional Policy And Human Geography $1: 2$ pp. 27-40.

[6.] Dávid L. - Bujdosó Z. - Tóth G. (2008) Tourism planning in the Hajdú-Bihar - Bihor Euroregion In: Süli-Zakar I (Süli-Zakar István Társadalomföldrajz) DE/TTK/FoldtI/Társadalomföldrajzi és Területfejlesztési Tanszék (szerk.) Neighbours and partners : on the two sides of the border Konferencia helye, ideje:: Debrecen, Magyarország 2008.11.10. - 2008.11.11.Debrecen: Kossuth Egyetemi Kiadó, pp 323-332 (2008)

[7.] Fejlesztési Koncepció Gyöngyös-Mátra Turisztikai desztináció, Gyöngyös-Mátra Turisztikai Közhasznú Egyesület, 2016 
[8.] Fejlesztési Koncepció Mátra Térségi TDM nonprofit Kft Turisztikai szervezetek (TDM) fejlesztéseGINOP - 1.3.4-15

[9.] Gyöngyös Város Idegenforgalmi Fejlesztési Koncepciója és Átfogó Stratégiája, 2015

[10.] Gyöngyös-Mátra Turisztikai Közhasznú Egyesület Versenyképességi és pozícionálási stratégia, 2011

\section{Szerzők:}

\section{Benkő Béla}

tanársegéd

Eszterházy Károly Egyetem

benko.bela@uni-eszterhazy.hu

\section{Szőke Szilvia}

TDM menedzser

Mátra Térségi TDM

\section{Gyurkó Ádám}

tanársegéd

Eszterházy Károly Egyetem

gyurko.adam@uni-eszterhazy.hu

\section{Dr. Zsarnóczky Martin}

fóiskolai docens

Kodolányi János Egyetem

martin@kodolanyi.hu

\section{Dr. habil. Bujdosó Zoltán}

föiskolai tanár

Eszterházy Károly Egyetem

bujdoso.zoltan@uni-eszterhazy.hu 